\title{
Bir Eğitim Araştırma Hastanesinde Santral Sinir Sistemi Enfeksiyonlarının Yedi Yıllık Değerlendirilmesi
}

\author{
Seven-Year Evaluation of Central Nervous System Infections in an Education Research
}

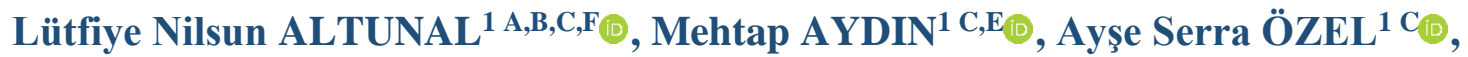

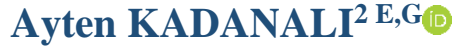 \\ ${ }^{1}$ Sağlık Bilimleri Üniversitesi, Ümraniye Eğitim ve Araştırma Hastanesi, Enfeksiyon Hastalıkları ve Klinik Mikrobiyoloji, \\ İstanbul, Türkiye \\ ${ }^{2}$ Biruni Üniversitesi Tıp Fakültesi, İstanbul, Türkiye
}

ÖZ

\begin{abstract}
Amaç: Santral sinir sistemi enfeksiyonları, acil tanı ve tedavi gerektiren morbidite ve mortalitesi yüksek enfeksiyonlardır. Hastanemizde takip edilen toplum kaynaklı santral sinir sistemi (SSS) enfeksiyonları irdelenerek hasta yönetiminde yardımcı olmak amaçlanmıştır.

Yöntem: Ümraniye Eğitim ve Araştırma Hastanesi’nde 2013 ve 2020 yılları arasında SSS enfeksiyonu tanısı konan 56 hasta retrospektif olarak değerlendirildi.

Bulgular: Yedi yıl içinde SSS enfeksiyonu tanısı konan 56 hastanın klinik sınıflaması incelendi. En sık akut pürülan menenjit (\%51.8), ikinci sırada aseptik menenjit-ensefalit (\%35.7) ardından tüberküloz menenjiti (\%12.5) olduğu görüldü. Akut pürülan menenjit hastalarının \%82.9'unda BOS kültürü sterildi. Bos kültüründe üreme olan hastalarda S. pneumonia (\%10.3) ve E. coli (\%6.8) saptand1. Aseptik menenjit ve ensefalitte \%10 oranında HSV1 PCR pozitifliği mevcuttu. Başvuru esnasında klinik ayırım yapılamadığı için ampirik olarak antiviral ve antibiyotik tedavisi beraber başlanan hasta oranı \%21.4 idi.

Sonuç: Çalışmamızda başvuru esnasında ensefalit ve menenjit ayrımı yapılamayan hastaların oranı dikkati çekicidir. Ayrıca hastaların çoğunluğunda etkenin izole edilemediği görülmüştür. Genel olarak kullanılan ampirik tedavilerin etken izolasyonunu etkileyebileceği kanaatine varılmıştır. Hastaların yönetiminde SSS enfeksiyonlarına neden olan etkenlerin dağılımının bilinmesi ampirik tedavi seçiminde yol gösterici olmaktadır.
\end{abstract}

Anahtar Kelimeler: Akut pürülan menenjit, Aseptik menenjit, Ensefalit.

ABSTRACT

Objective: Central nervous system infections are infections with high morbidity and mortality that require urgent diagnosis and treatment. We aimed to help patient management by examining the CNS infections followed in our hospital.

Methods: The data of 56 patients who were diagnosed with SSS infection between 2013 and 2020 in Ümraniye Training and Research Hospital were evaluated retrospectively.

Results: The clinical classification of 56 patients diagnosed with CNS infection in seven years was examined. Bacterial meningitis (51.8\%) was the most common type, aseptic meningitis- encephalitis (35.7\%) was in the second order and followed by tuberculosis meningitis (12.5\%). $87.2 \%$ of the patient's CSF culture was sterile, S. pneumonia (10.3\%) and E. coli (6.8\%) were detected in CSF cultere. HSV1 PCR positivity was $10 \%$ in aseptic meningitis and encephalitis. Empirically, antiviral and antibiotic treatment was initiated together with $21.4 \%$.

Conclusion: In our study, the proportion of patients who could not distinguish between encephalitis and meningitis at the time of application is remarkable. In addition, it was observed that the agents could not be isolated in the majority of patients. It was concluded that the distribution of agents used in general empirical treatments can change the frequency order. Knowing the distribution of causative agents of CNS infections in the management of patients guides empirical treatment selection.

Sorumlu Yazar: Lütfiye Nilsun ALTUNAL

Sağlık Bilimleri Üniversitesi, Ümraniye Eğitim ve Araştırma Hastanesi, Enfeksiyon Hastalıkları ve Klinik Mikrobiyoloji, İstanbul, Türkiye

1.nilsun@hotmail.com

Geliș Tarihi: 18.07.2020 - Kabul Tarihi: 31.01.2021

Yazar Katkıları: A) Fikir/Kavram, B) Tasarım, C) Veri Toplama ve/veya İșleme, D) Analiz ve/veya Yorum, E) Literatür

Taraması, F) Makale Yazımı, G) Eleştirel İnceleme 
Key words: Acute purulent meningitis, Aseptic meningitis, Encephalitis.

\section{GİRIŞ}

Santral sinir sistemi (SSS) enfeksiyonu erken tanı ve tedavi yapılamadığı durumlarda kalıcı nörolojik hasara veya mortaliteye sebep olmaktadır. Santral sinir sistemi enfeksiyonları, halk sağlığındaki iyileşmeler, çocukluk çağı aşılama programları ve iyi kalitedeki acil bakım hizmetlerine rağmen, hala yüksek morbidite ve mortalitesi nedeniyle günümüzde önemini koruyan bir hastalıktır.

Hastalar genellikle ateş, baş ağrısı, bilinç değişikliği ve fokal nörolojik bulgularla başvurabilmektedirler. Uluslararası rehberlerin önerileri doğrultusunda agresif tedavi yaklaşımı gözetmek gerekebilmektedir (1). SSS enfeksiyonlarının etiyolojik dağılımı; yaş, coğrafi farklılıklar, popülasyonun belirli etkenlere karşı duyarlılığı, mevsim, genetik yapı ve lokal endemik faktörlere göre değişiklik gösterebilir. Tanıda lomber ponksiyon ile beyin omurilik sıvısın (BOS) biyokimyasal ve mikrobiyolojik incelenmesi esastır (2). Akut bakteriyel menenjitte $S$. pneumoniae en s1k saptanan etken iken aseptik menenjitte izole edilebilen etkenler içinde ilk sırayı Enterovirüsler (\%85-95) almaktadır (3,4).

Çalışmamızda, son yedi yılda hastanemizde takip edilen SSS enfeksiyonları irdelenerek hasta yönetiminde yardımcı olmak amaçlanmıştır.

\section{GEREÇ VE YÖNTEMLER}

Sağlık Bilimleri Üniversitesi Ümraniye Eğitim ve Araştırma Hastanesi’nde Şubat 2013Şubat 2020 tarihleri arasında 18 yaşından büyük SSS enfeksiyonu tanısı alan hastaların dosyaları retrospektif olarak incelendi. Yedi yıllık sürede 56 hasta tespit edildi. Hastalar klinik bulguları, beyin omurilik sıvısı (BOS) değerlendirmesindeki bulguları (beyaz küre sayısı, hakim olan hücre tipi, protein, glukoz değerleri, BOS/kan glukoz oranı) ve kraniyal görüntüleme bulgularına göre pürülan menenjit, aseptik menenjit ve ensefalit, tüberküloz menenjiti tanıları ile gruplandırıldı.

BOS örnekleri kanlı agar, çikolata agar ve Eosin Methylene Blue (EMB) agara ekilerek $37^{\circ} \mathrm{C}$ 'de $24-48$ saat inkübe edildi. İnkübasyon sonunda üreyen bakterilerin tanımlanmasında konvansiyonel ve otomatik (VITEK 2, bioMérieux, Fransa) değerlendirme yöntemleri kullanıld1. Viral menejit panelinde HSV1, HSV2, VZV, Enterovirüs, Parechovirüs multiplex PCR (Montanıa 4896 Real-Time PCR, Anatola Geneworks) ile çalışıldı. M. tuberculosis için konvansiyonel kültür yöntemleri ve real time PCR (GenXpert Ultra, Cepheid) kullanıldı.

Başvuru şikayetleri, muayene ve BOS bulguları, klinik özellikleri, komplikasyon ve mortalite oranları gibi bilgiler retrospektif olarak hasta dosyalarından elde edildi.

Çalışmanın etik kurul onayı Sağlık Bilimleri Üniversitesi Ümraniye Eğitim ve Araştırma Hastanesi Etik Komitesi'nden alındı (Karar No: 136).

\section{BULGULAR}

Çalışmaya dahil edilen 56 hastanın \%57'si kadın, yaş ortalaması $54.9 \pm 6.5$ idi. Hastaların 54’ü (\%96.5) Türk vatandaşıydı. Hastaneye başvuru şikayetleri incelendiğinde en sık ateş (\%78), baş ağrısı (\%73), bilinç değişikliği (\%30) olduğu görüldü. Hastaların 24'ünde (\%43) SSS irritasyon bulgusu mevcuttu. Hastaların klinik sınıflaması irdelendiğinde, 29 hasta akut 
bakteriyel menenjit (\%51.8), 20 hasta aseptik menenjit ve ensefalit (\%35.7), yedi hasta tüberküloz menenjiti (\%12.5) olarak gruplandırıldı (Tablo 1).

Tablo 1. SSS enfeksiyonu tanısı konan hastaların demografik özellikleri

\begin{tabular}{llll}
\hline Demografik özellikler & & Sayı & \% \\
\hline Cinsiyet & Kadın & 32 & 57 \\
\hline & Erkek & 24 & 43 \\
\hline Yaş ortalaması (yıl) & & $54.9 \pm 6.5$ & \\
\hline Şikayet ve fizik inceleme bulguları & & 44 & 78 \\
\hline & Ateş & 41 & 73 \\
\hline & Baş ağrısı & 30 \\
\hline & Bilinç değişikliği & 17 & 43 \\
\hline Tanı & SSS irritasyon bulgusu & 24 & 51.8 \\
\hline & & 29 & 35.7 \\
\hline & Bakteriyel menenjit & 29 & 12.5 \\
\hline & $\begin{array}{l}\text { Aseptik menenjit- } \\
\text { ensefalit }\end{array}$ & 20 & \\
\hline & Tüberküloz menenjiti & 7 & \\
\hline
\end{tabular}

Bir hastaya kontrendike olduğu için lomber ponksiyon yapılamadı. Otuz dört hastanın (\%62) BOS glukozu eş zamanlı kan şekerinin üçte birinden düşük saptandı. Ortalama BOS proteini $142.8 \mathrm{mg} / \mathrm{dL}$ idi. BOS incelemesinde ortalama $1238 \mathrm{~mm} 3$ hücre say1ld1.

Akut pürülan menenjit hastalarının \%82.9'unda BOS kültürü sterildi. Üç hastanın Bos kültüründe S. pneumonia (\%10.3), iki hastanın ise E. coli (\%6.8) üredi. Aseptik menenjitensefalitte ise $\% 10$ oranında HSV1 PCR pozitifliği saptand. Başka viral etken izole edilemedi. Tüberküloz menenjiti kliniği ile takip edilen hastaların üçünde (\%42.8) BOS kültüründe $M$. tuberculosis üredi, ikisinde (\% 28.5) PCR pozitifliği saptandı.

Aseptik menenjit tanısı konan hastaların kraniyal MR'ları incelendiğinde; üç hastada temporal lobda, bir hastada paryetal lobda, bir hasta da ise frontaparyetal lobda T2 hiperintens lezyonlar olduğu görüldü.

Hastaneye ilk başvuru esnasındaki klinik bulgularıyla ensefalit veya menenjit ayırımı yapılamadığı için antiviral ve antibakteriyel tedavinin beraber başlandığı hasta sayısı ise 12 (\%21.4) idi.

Komplikasyonlar açısından değerlendirildiğinde altı hastada enfakt (\%10.8), üç hastada hidrosefali (\%3.6) geliştiği saptandı. Klinik takiplerinde 56 hastanın beşi (\%8.9) exitus oldu, dördünün (\%7.1) yoğun bakım ihtiyacı olması nedeniyle dış merkeze sevk edildiği görüldü (Tablo 2). 
Adnan Menderes Üniversitesi Sağllk Bilimleri Fakültesi Dergisi 2021: 5(2); 170-176

Journal of Adnan Menderes University Health Sciences Faculty

Tablo 2. Mortalite ve yoğun bakım ihtiyacı gelişen olguların özellikleri

\begin{tabular}{llllll}
\hline Olgu & Yaş & Cinsiyet & Klinik sınıflandırma & Komplikasyon & Klinik takip \\
\hline 1 & 74 & Erkek & Aseptik menenjit-ensefalit & Yok & Yoğun bakım desteği \\
\hline 2 & 74 & Kadın & Tüberküloz menenjiti & Hidrosefali & Exitus \\
\hline 3 & 73 & Erkek & Aseptik menenjit-ensefalit & Yok & Yoğun bakım desteği \\
\hline 4 & 70 & Kadın & Aseptik menenjit-ensefalit & Yok & Yoğun bakım desteği \\
\hline 5 & 59 & Erkek & Aseptik menenjit-ensefalit & Enfarkt & Yoğun bakım desteği \\
\hline 6 & 31 & Kadın & Bakteriyel Menenjit & Hidrosefali & Exitus \\
\hline 7 & 64 & Kadın & Aseptik menenjit-ensefalit & Yok & Exitus \\
\hline 8 & 32 & Erkek & Bakteriyel menenjit & Yok & Exitus \\
\hline 9 & 56 & Kadın & Bakteriyel menenjit & Yok & Exitus \\
\hline
\end{tabular}

\section{TARTIŞMA}

SSS enfeksiyonları, etken mikroorganizma, hastanın bağışıklık durumu, etkin tedavi başlama zamanı gibi bir çok faktöre göre klinik seyri değişebilen bir enfeksiyon hastalığıdır.

Ateş, baş ağrısı ve bilinç değişikliği ile başvuran hastalarda en hızlı yapılması gereken SSS enfeksiyonu ayırıcı tanısıdır. Van de Beek ve arkadaşlarının yaptığı bir çalışmada akut bakteriyel menenjit tanısı konan hastaların başvuru şikayetleri değerlendirildiğinde \%87'sinde baş ağrıs1, \%83'ünde ense sertliği, \%7'sinde ateş olduğu görülmüştür (5). Bizim çalışmamızdaki bulgularda ise en sık ateş (\%78) saptandı. Bu durumun hastalarımızın \% 35.7'sinin viral etkenlere bağlı olmasından kaynaklandığını düşünmekteyiz. Ensefalitlerin dahil edildiği çok merkezli bir çalışmada $\% 72$ ateş, \%60 baş ağrısı, \%23 ense sertliği geliştiği bildirilmiştir (6). Çalışmamızdaki ateş ve baş ağrısı oranları literatür ile benzer bulunmuştur.

SSS enfeksiyonlarında, erken tanı, etkenin tespiti ve etkene göre tedavinin düzenlenmesi hayat kurtarıcıdır (7). Bakteriyel etkenlerin tayininde, konvansiyel kültür yöntemleri ile antibiyotik tedavisi almayan hastalarda \%70-\%80 etken izolasyonu mümkün olabileceği belirtilmiştir. (2). Ancak ülkemizde yapılan çok merkezli prospektif bir çalışmada konvansiyonel yöntemlerle bu oran \%21.7, PCR ile \%58.6 bulunmuştur (8). Bizim çalışmamızda da benzer olarak konvansiyonel yöntemlerle bakteri identifikasyon oranı \%17.1'dir. İleri moleküler tetkiklerin kullanılması ile etken izolasyon oranımızın artacağ düşünülmektedir.

Bakteriyel menenjitlerin büyük çoğunluğunu $S$. pneumoniae, N. meningitidis, $H$. influenzae ve L. monocytogenes oluşturmaktadır $(9,10)$. Çalışmamızda da en sık izole edilen etkenin S. pneumoniae, ardından E. coli olduğu görüldü. Uluslararası rehber önerileri doğrultusunda SSS enfeksiyonunun ampirik tedavisinde en sık rastlanan etkenlere yönelik olarak genellikle üçüncü kuşak sefalosporin ve vankomisin kullanılmaktadır $(1,2)$. Ülkemizde yaptığımız çok merkezli çalışmada da görüldüğü gibi $E$. coli suşlarında 3. kuşak sefalosporin 
direncinin \%60'larda olduğu bilinmektedir (11). Genel olarak kullanılan ampirik tedavilerin etken dağılımının sıklık sırasını değiştirebilmektedir. Bununla birlikte 50 yaş üstündeki hastalarda aerobik gram negatif bakteriler de sık görülen bakteriyel menenjit etkenleri arasında sayılmaktadır (12). Bizim çalışmamızda yaş ortalaması 54 olarak saptanmıştı. E.coli'nin ikinci sıklıkta görülmesi çalışmaya alınan hastaların yaş ortalamasının 50'nin üzerinde olmasından kaynaklanabileceğini düşünmekteyiz.

Diğer etkenlerin izolasyonunda da \%32-75'inde ileri tanı yöntemleri (serolojik testler, doku biyopsisi, hücre kültürü, moleküler yöntem vb.) kullanılmasına rağmen etiyolojik etken belirlenememektedir (4,8,13). Ensefalitlerin de \%37-62'sinde etken identifikasyonu yapılamamaktadır (14). New York'da yapılan bir çalışmada PCR ile incelenen 340 BOS örneğinde HSV pozitifliği \% 2.8 bulunmuştur (15). Terzi ve arkadaşlarının çalışmasında ise bu oran ise \%4.5 saptanmıştır (16). Ülkemizde viral etyolojinin araştırıldığı retrospektif bir çalışmada ise nükleik asit testleri (NAT) ile \%2.3 oranında etken izole edilebilmiştir (17). Çalışmamızda, ileri tanı yöntemlerinden viral etkenler için multiplex PCR kullanılmış ve \%10 oranında HSV1 PCR pozitifliği saptanmıştır. Kliniğimizde, SSS enfeksiyonu düşünülen her hastadan viral PCR panelinin çalışılmasının oranımızı arttırdığı düşünülmektedir.

Herpes ensefalitlerinde tanısal amaçlı yapılan en duyarlı görüntüleme yöntemi MR'dır. T2 ağırlıklı ve FLAIR sekansda temporal, inferior frontal loblarda ve insular korteksde ödeme sekonder hiperintesite görülmesi beklenen bulgudur. Sili ve arkadaşlarının yaptığı retrospektif bir çalışmada herpes ensefaliti tanısıyla takip edilen 106 hastanın kraniyal MR'ında $\% 95$ oranında tutulum olduğu görülmüştür (18). Bizim çalışmamızda ise bu oran $\% 25$ bulundu. $\mathrm{Bu}$ durumun çalışmamızda aseptik menenjit ve ensefalitlerin aynı grupta değerlendirilmesinden kaynaklandığını düşünmekteyiz.

Hastaların ampirik tedavi seçiminde yol gösterici olacak yöntem BOS hücre sayımı ve biyokimyasal incelemesidir $(1,2,3)$. Ancak her zaman hastanın acil başvuru kliniği ve BOS bulgularıyla ayırıcı tanı yapılamayabilmektedir (19). Çalışmamızda başvuru esnasında klinik ve BOS bulgularıyla ensefalit veya menenjit ayırımı yapılamadı̆̆ için antiviral ve antibakteriyel tedavinin beraber başlandığ 1 hasta oranımız \%21.4'tü. Etkin tedavinin hızla başlanamadığı durumlarda kliniğin mortal seyretmesinin arada kalınan vakalarda kombine tedavi başlama oranımızı etkilediği düşünülmüştür.

SSS enfeksiyonu olan hastalarda, serebral ödem, hidrosefali, serebral enfarkt ve nöbet gibi komplikasyonlara rastlanabilmektedir $(9,14)$. Bizim çalışmamızda hastaların \%10.8'inde enfarkt, \%3.6'sında hidrosefali gelişti. Kötü prognozu gösteren bu bulgulardan enfarkt gelişen bir hastanın yoğun bakım ihtiyacı, hidrosefali gelişen iki hastamız da exitus olmuştur.

Çalışmamızda mortalite ve yoğun bakım ihtiyacı gelişen dokuz hastanın beşi aseptik menejit-ensefalit, üçü bakteriyel menenjit, biri tüberküloz menenjiti tanısıyla takip edildi. Yapılan çalışmalarda zamanla menenjit sıklı̆̆ında azalma olmasına rağmen, olgu fatalite hızının değişmediği görülmüş. 1998, 1999 yıllarında bu oran \%15.7 iken 2006, 2007 de \%14.3 bulunmuş (3). Bizim çalışmamızda ise dış merkeze sevk edilen hastaların akibeti bilinmediği için değerlendirme yapılamamıştır. 


\section{SONUÇ VE ÖNERİLER}

Çalışmamızda başvuru esnasında ensefalit ve menenjit ayrımı yapılamayan hastaların oranı dikkati çekicidir. Bu durum hastaların ampirik tedavisinde klinisyeni geniş spektrumlu kombine antimikrobiyal tedaviye yöneltmektedir. Çalışmamız bu konuda literatüre katkıda bulunacaktır. Tanı ve tedavide yol gösterici olması için hasta sayılarının fazla olduğu çok merkezli çalışmalara ihtiyaç vardır.

\section{Araştırmanın Etik Yönü}

Çalışmanın etik kurul onayı Sağlık Bilimleri Üniversitesi Ümraniye Eğitim ve Araştırma Hastanesi Etik Komitesi'nden alındı (Karar No: 136).

\section{Çıkar Çatışması}

Yazarlar arasında çıkar çatışması yoktur.

\section{KAYNAKLAR}

1. Van de Beek, D., Cabellos, C., Dzupova, O., Esposito, S., Klein, M., Kloek, AT., et al. (2016). ESCMID guideline: diagnosis and treatment of acute bacterial meningitis. Clin Microbiol Infect, 22(3), 37-62.

2. Tunkel, A. R., Hartman, B. J., Kaplan, S. L., Kaufman, B. A., Roos K. L., Scheld W. M., et al. (2004). Practice guidelines for the management of bacterial meningitis. Clin Infect Dis, 39, 1267-84.

3. Tunkel, A., van de Beek, D., Scheld, M. (2015). Acute Meningitis. Gerald LM, John EB, Raphel D. Principles and Practice of Infectious Diseases. 8th ed. (ss. 1097-137). Philadelphia: Elsevier.

4. Tunkel, A. R., Glaser, C. A., Bloch, K. C., Sejvar, J. J., Marra, C. M., Rooset, K .L., et al. (2008). The management of encephalitis: clinical practice guidelines by the Infectious Diseases Society of America. Clin Infect Dis, 47(3), 303-27.

5. Van de Beek., D., de Gans, J., Spanjaard, L., Weisfelt, M., Reitsma, J. B., Vermeulenet, M., al. (2004). Clinical features and prognostic factors in adults with bacterial meningitis. $N$ Engl J Med, 351(18), 1849-59.

6. Granerod, J., Ambrose, H. E., Davies, N. W., Clewley, J. P., Walsh, A. L., Morgan, D., et al. (2010). Causes of encephalitis and differences in their clinical presentations in England: a multicentre, population-based prospective study. Lancet Infect Dis, 10, 83544.

7. Kadanal1, A. Santral Sinir Sistemi İnfeksiyonları. (2007). The Eurasian Journal of Medicine, 39, 219-23.

8. Kahraman, H., Tünger, A., Şenol, Ş., Gazi, H., Avc1, M., Örmen, B., et al. (2017). Investigation of bacterial and viral etiology in community acquired central nervous system infections with molecular methods. Mikrobiyol Bul, 51(3), 277-285.

9. Schut, E. S., Gans, J. D., Beek, D. V. D. (2008). Community-acquired bacterial meningitis in adults. Practical Neurology, 8(1), 8-23.

10. Arda, B., Sipahi, O. R., Atalay, S., Ulusoy, S. (2008). Pooled analysis of 2.408 cases of acute adult purulent meningitis from Turkey. Med Princ Pract, 17, 76-9. 
11. Aydın, M., Ergönül, Ö., Azap, A., Bilgin, H., Aydın, G., Çavuşet, S. A., et al. (2018). Rapid emergence of colistin resistance and its impact on fatality among healthcareassociated infections. J Hosp Infect. 98(3), 260-263.

12. Domingo, P., Pomar, V., Benito, N., Coll, P. (2013). The spectrum of acute bacterial meningitis in elderly patients. BMC Infectious Diseases, 13, 108.

13. Başpınar, E. Ö., Dayan, S., Bekçibaşı, M., Tekin, R., Ayaz, C., Deveci, Ö., et al. (2017). Comparison of culture and PCR methods in the diagnosis of bacterial meningitis. Braz J Microbiol, 48(2), 232-6.

14. Ellul, M., Solomon, T. (2018). Acute encephalitis-diagnosis and management. Clin Med, 18(2), 155-159.

15. Dupuis, M., Hull, R., Wang, H., Glasheen, B., Fusco, H., Dzigua, L., et al. (2011). Molecular detection of viral causes of encephalitis and meningitis in New York State. $J$ Med Virol, 83, 2172-81.

16. Terzi, H. A., Aydemir Ö., Karakeçe, E., Köroğlu, M., Altındiş, M., (2018). Viral Ensefalit / Menenjit Şüpheli Hastalarda,Beyin Omurilik Sıvısı Örneklerinde Herpes Simplex Virüslerinin Real-Time PZR ile Araştırılması. Süleyman Demirel Üniversitesi Sağllk Bilimleri Dergisi, 9 (4), 17-20.

17. Zeytinoğlu, A., Erensoy, S., Sertöz, R., Altuğlu, İ., Çiçek, C., Kayın, M. ve ark. (2017). Santral sinir sistemi enfeksiyonlarında viral etiyolojinin İzmir'de bir üniversite hastanesinin yedi yıllık verileri üzerinden değerlendirilmesi. Mikrobiyol Bul, 51(2), 127-135.

18. Sili U., Kaya A., Mert A., HSV Encephalitis Study Group. (2014). Herpes simplex virus encephalitis: clinical manifestations, diagnosis and outcome in 106 adult patients. $J$ Clin Virol, 60, 112-118.

19. McKinney, W. P., Heudebert, G. R., Harper, S. A., Young, M. J., McIntireet, D. D., et al. (1994). Validation of a clinical prediction rule for the differential diagnosis of acute meningitis, J Gen Intern Med, 9, 8-12. 